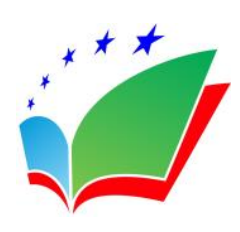

European Journal of Physiotherapy and Rehabilitation Studies

ISSN: 2668-9928

ISSN-L:2668-9928

Available on-line at: $\underline{\text { www.oapub.org/hlt }}$

DOI: 10.46827/ejprs.v2i1.98

Volume 2 | Issue 1 | 2021

\title{
EXERCISE INTERVENTION IN THE MANAGEMENT OF VENOUS LEG ULCERS: A REVIEW
}

\author{
Samantha Barker', \\ Michael Ross ${ }^{2 i}$, \\ Kehua Zhou ${ }^{3}$ \\ 1DPT; Physical Therapist, \\ Physical Therapy Department, \\ Daemen College, Amherst, NY, USA \\ 2PT, DHSc; Associate Professor, \\ Physical Therapy Department, \\ Daemen College, Amherst, NY, USA \\ ${ }^{3} \mathrm{MD}$, DPT; Hospitalist Physician, Attending Physician, \\ ThedaCare Regional Medical Center \\ Appleton/Neenah, WI, USA
}

\begin{abstract}
:
Venous leg ulcers (VLUs) are the most common etiology of lower extremity ulceration, with approximately 70 to 80 percent of leg ulcers developing from venous insufficiency or disease. The financial burden of VLUs on society, increase in prevalence with age, the chronic nature of the disorder, and high recidivism rate are, in part, the driving forces behind efforts to determine the most effective management options to achieve complete wound healing in a timely and efficient manner. Thus, the purpose of this paper is to describe the etiology, diagnosis, and management of VLUs, with a particular emphasis on exercise intervention. While medical treatment of VLUs include wound debridement, infection control, and proper wound dressing, compression therapy and elevation are the most common and effective treatment option for VLUs. When combined with routine compression therapy, exercise intervention (e.g., aerobic, resistance, and flexibility exercises) significantly improves the healing of VLUs in a cost efficient manner and should be strongly considered in the routine management of patients with VLUs.
\end{abstract}

Keywords: venous leg ulcer, exercise, wound care

${ }^{\mathrm{i}}$ Correspondence: Affiliation and mailing address: Department of Physical Therapy, Daemen College, 4380 Main St, Amherst NY, 14226, Email: $\underline{\text { mross@daemen.edu }}$ 


\section{Introduction}

Venous leg ulcers (VLUs) are the most common etiology of lower extremity ulceration, with approximately 70 to 80 percent of leg ulcers developing from venous insufficiency or disease $(1,2)$. In 2010, the estimated annual financial burden for medical costs for VLUs was $\$ 2$ billion (3); however, in 2017, the estimated costs increased to $\$ 9$ billion (4). Approximately 1 percent of the United States population is diagnosed with a VLU, but the prevalence increases to 2 percent for people over 65 years of age in the United States $(1,5-7)$. Venous leg ulcers are often chronic and there is usually uncertainty in the amount of time that it will take for the ulcer to fully heal. For example, between 40 to 70 percent of VLUs heal after 6 months of treatment; however, the larger the ulcer, the decreased likelihood of complete wound healing (8-10). Additionally, if the underlying cause of the VLU is not addressed, it is likely that the ulcer will recur. The financial burden of VLUs on society, increase in prevalence with age, the chronic nature of the disorder, and high recidivism rate are, in part, the driving forces behind efforts to determine the most effective management options to achieve complete wound healing in a time efficient manner. The purpose of this paper is to describe the etiology, diagnosis, and management of VLUs, with a particular emphasis on exercise intervention.

\section{Etiology and Diagnosis}

Patients present with venous insufficiency when veins become incompetent in returning blood to the heart. The lower extremity has major muscle pumps located in the calf, thigh, and foot (11). The calf muscle pump, consisting of the soleus and gastrocnemius muscles, is important for its ability to generate high pressures and assist venous blood flow against the force of gravity $(12,13)$. Factors that may lead to venous incompetence and insufficiency include decreased mobility, decreased effectiveness of the calf muscle pump, venous valve dysfunction, venous thrombosis, or phlebitis $(14,15)$. Over time, venous insufficiency leads to leg veins becoming dilated and retrograde blood flow results in venous hypertension in the lower extremities. A sustained increase in venous pressure leads to extraction of fluid and proteins in the extracellular space, which results in edema, extravasation of red blood cells, and altered pigmentation of the local tissues. Persistent edema, inflammation, hypoxia, and oxidative stress causes mechanical disruption of endothelial cells and dermal tissues, which can lead to subsequent ulcer formation (16-18).

Normal ankle mobility is crucial for the activation of the calf muscle pump $(19,20)$. Patients diagnosed with VLUs commonly present with impaired ankle range of motion, which is associated with delayed ulcer healing. $(19,20)$. Other risk factors for developing VLUs include advanced age, female gender, a family history of leg ulcers, white race, previous leg injury or trauma that damages the integument, chronic leg edema, sedentary lifestyle, and prolonged standing $(21,22)$.

When evaluating VLUs, a thorough and careful history and physical examination are key, as these findings will be helpful for developing an accurate prognosis and an 
appropriate management plan. Historical information should include whether there is a history of previous or current deep vein thrombosis, a family history of leg ulcers, varicose veins, phlebitis, chest pain, pulmonary embolism, occupations that have required prolonged standing or sitting, obesity, number of pregnancies for women, aching pain in the lower limbs, and/or surgery, trauma or fractures that could damage the venous valves or integument (23). Examination of the ulcer should include identifying the location, size, and characteristics of the ulcer, amount and type of exudates, appearance of the ulcer bed, ulcer odor, any sign of infection, and pain associated with the ulcer $(24,25)$. The location of a VLU is typically anterior to the medial malleolus and in the lower third of the leg. Measuring for the size of the ulcer is important to determine a prognosis for the patient. Measurements should include the length, width, and depth of the ulcer. Venous stasis ulcers typically present as shallow in depth and irregularly shaped with well-defined margins (Figure 1). Any exudates that may be present would display as yellow-white in color. Patients with VLUs present with variable pain symptoms; however, pain is typically worse at the end of the day and is typically relieved by elevation of the leg. Signs of infection need to be observed daily and are important for any health care provider to identify when treating a patient with a VLU. Signs of infection include the following: erythema, delayed healing despite appropriate treatment, increase in local skin temperature, increase in ulcer pain or changing in the nature of the pain, newly formed ulcers, discoloration, increase in exudate viscosity or volume, new-onset dusky wound hue, sudden appearance or increase in the amount of slough, and/or sudden appearance of necrotic black spots and ulcer enlargement (26).

\section{Medical Management}

General guidelines for medical treatment of VLUs include wound debridement, infection control, wound dressing, and compression therapy (18). Wound debridement involves removing tissue and decreasing the bacterial burden that can be accomplished by a faster, but more traumatic surgical option or through autolytic dressings that are slower, but less traumatic (27). After debridement, topical antibiotics (such as neomycin/polymyxin $\mathrm{B} /$ bacitracin separately or in combination, or mupirocin) and antiseptics (like acetic acid, iodine dressing, or hydrogen peroxide) may be applied to the ulcer to control for potential local infections. Topical antibiotics and antiseptics can both decrease bacterial burden in the wound; however, this may not always translate into wound healing, especially when deep tissue infection or wound etiology remains untreated.

If a deep or systemic infection is suspected, systemic antibiotics for the treatment of cellulitis or soft tissue infection should be introduced. Per guidelines from the Infectious Diseases Society of America (28), skin and soft tissue infections are divided into purulent and non-purulent. Purulent infections are usually caused by $S$. aureus (methicillin sensitive or methicillin resistant depending on situations) which is usually treated with oral doxycycline, minocycline, or trimethoprim-sulfamethoxazole in mild cases and with intravenous vancomycin, daptomycin, or linezolid in moderate to severe cases. Non-purulent infections are typically caused by streptococcus and occasionally 
methicillin sensitive $S$. aureus which is treated with oral dicloxacillin, cephalexin, or clindamycin in mild cases and with intravenous nafcillin, oxacillin, cefazolin, ceftriaxone or clindamycin in moderate to severe conditions. Additionally, skin or soft tissue infection of $P$. aeruginosa (commonly noticeable for its blue-green pigmentation from pyocyanin) is not uncommon in VLUs (29), especially in patients with diabetes or other multiple comorbidities. Consequently, expanding coverage with additional oral or intravenous levofloxacin or ciprofloxacin, or intravenous piperacillin-tazobactam or carbapenems is also needed when $P$. aeruginosa infection is a concern.

Local infection, also known as, critical colonization refers to the status of wound infection without inducing an overt host response (30). Wounds and the surrounding soft tissue with critical colonization commonly lack the typical signs of redness, edema, warmness, or significant tenderness. While the use of topical antibiotics or antiseptics may be justified in critical colonization because it hinders wound healing, no evidence is present supporting the prolonged or routine use of antibiotics, especially in non-infected wounds (1). Certainly, the diagnosis of pure phlebitis does not warrant antibiotics. When considering local wound dressings for patients with VLUs, topical dressings should be utilized to create an optimal environment for wound healing, neither too dry nor too moist, while protecting the wound from further injury and shear. Potential wound dressings that are available include hydrocolloids, alginates, and foams depending on the needs of the patient and state of the wound (31). Other management strategies that have shown promise include ultrasound therapy, electrical stimulation, extra-corporeal shock-wave therapy, and aspirin therapy (18).

Compression therapy and elevation are the most common and effective medical treatment options for VLUs (18). It is imperative that medical compression therapy be prescribed accurately, to ensure that no tissue damage occurs, and the patient is compliant with the management protocol. Prior to incorporating compression therapy for a patient, it is necessary to rule out arterial insufficiency as this is an absolute contraindication (32). Elastic compression garments are preferred over non-elastic with graded pressure in a distal to proximal direction $(33,34)$. Additionally, four-layer bandages appear better than the short stretch bandage with respect to facilitating healing (33). The compression garment should be applied from the foot (sometimes toes depending on the need) to the knee with inclusion of the heel for maximum healing benefits (34). Typically, patients will receive compression garments that range from 30 to $40 \mathrm{mmHg}$ of compression, but the amount of compression applied should be based upon several factors including the ankle-brachial pressure index, disease progression and clinical symptoms, patient body mass index, and limb shape and description (34).

\section{Exercise Considerations}

Up to 30 percent of chronic VLUs do not respond to compression therapy alone and remain unhealed even after a year of treatment, which suggests an alternative adjunct treatment is necessary, such as exercise $(34,35,36)$. Exercise can serve as both a preventative measure and treatment option (37). Patients with VLUs have decreased 
ankle range of motion and ankle plantarflexor strength, as well as impaired balance and gait in comparison to healthy individuals of equal age (38). Thus, exercise treatments should address these key impairments with a focus on activating the calf muscle pump during gait to promote improved blood circulation.

Prior to initiating an exercise program, it is recommended that clinicians thoroughly screen patients for cardiovascular risk factors. By identifying the level of cardiovascular risk for each patient, the clinician can determine whether medical clearance is necessary prior to initiating an exercise program. It is also important to assess the patient's current level of function. Submaximal exercise tests, such as the 6-minute walk test, timed-up and go test, and the 30-second chair stand test, are helpful to establish an initial exercise prescription and serve as a baseline measure to assess future progress. The 6-minute walk test assesses the distance walked over a 6-minute time period, which would assess aerobic endurance and gait capabilities, which is likely limited in patients with a VLU. The timed-up and go test assesses a patient's mobility and their static and dynamic balance. It assesses the time that a person takes to get up from a seated position in a chair, walk 3 meters, turn around, walk back to the chair, and return to the seated position. The 30-second chair stand test, which has a patient rise to a full standing position and then sit back down again as many times as they can in a 30 second period, assesses leg strength, balance, and endurance of the patient. These submaximal exercise tests along with ankle range of motion and strength of the ankle plantarflexors are important to include to assess the key impairments associated with patients with VLUs.

Since patients with VLUs may have pain and other impairments related to gait and balance that may interfere with an exercise program, and perhaps limited experience with exercise, it is prudent to begin an exercise program in-clinic under the appropriate level of clinical supervision. A study conducted by Klonizakis et al (39), evaluated the feasibility of a 12-week supervised exercise program as an adjunct to compression therapy in older patients (mean age $=64$ years) with VLUs (mean ulcer duration $=8$ months) (Table 1). Assessments were completed at baseline and repeated at 12 weeks, 6 months and 1 year. While all participants received standard compression therapy, the individuals in the exercise group were enrolled in a 60-minute supervised exercise program that was completed 3 times per week and incorporated a combination of aerobic, resistance, and flexibility exercises (Table 2). Patients in the exercise group demonstrated higher mean values in the physical fitness tests (6-minute walk test, chair sit and reach, chair sit and stand) and ankle range of motion at 3 months, but stabilized in all measures in relation to the non-exercise group by 12 months. When examining outcomes at 1 year, median VLU healing time was lower in the exercise group (13 versus 35 weeks) and mean costs for care were 3 times higher for those individuals in the control group. The results of this study suggest that patients who participate in an exercise program, in addition a routine compression therapy, would have improvements in physical fitness and wound healing in a shorter period of time in comparison to patients that do not exercise.

Another management option would be for patients with VLUs to be primarily managed through a home-based exercise program. In a randomized control trial, $\mathrm{O}^{\prime}$ Brien 
et al (37) assessed the impact of a home-based progressive resistance exercise program for the calf musculature in addition to routine evidence-based care on the healing rates for adults with VLUs. This study included 63 patients with VLUs (mean age $=72$ years; mean ulcer duration $=16$ weeks) $($ Table 1$)$. Patients were randomized to receive either a 12-week progressive resistance exercise program (Table 3) with a telephone coaching component or usual care plus telephone calls. The primary outcome evaluated the effectiveness of the intervention in relation to wound healing. At 12 weeks, 77 percent of those in the intervention group healed compared to 53 percent of those in the usual care group. The authors concluded that those participants who adhered to the exercise program as an adjunctive treatment to routine evidence-based care are more likely to heal and have better functional outcomes than those who do not adhere to the exercises in conjunction with usual care. Thus, a self-management intervention that improves an individual's exercise self-efficacy and self-management capacity is a viable treatment option for patients with VLUs.

Compression therapy is the most common and effective medical treatment option for VLUs (18). In a randomized controlled trial conducted by Meagher et al (35), researchers hypothesized that adjunctive exercise therapy in combination with compression therapy might increase the rate of healing of VLUs. Thirty-five patients participated in the study; 18 patients were in the exercise group (median age $=66$ years) and 17 patients were in the control group (median age $=78$ years) (Table 1 ). All patients were treated with multilayer compression stockings during the duration of the study. The exercise group was instructed to try and increase their walking to 10,000 steps a day while the control group was instructed to not change anything out of their daily routine. Meagher et al (36) found that the more steps a patient took compared to baseline, the higher the VLU healing rate. More specifically, 67 percent of the participants in the exercise group achieved VLU healing by 8 weeks, compared with 35 percent of individuals in the control group. The results of this study emphasize the importance of exercise therapy in patients with VLUs and how exercise should be used in conjunction with other medical interventions, such as compression therapy, for treating VLUs.

It is common for patients with VLUs to have an increased incidence of medical comorbidities such as cardiac disease and diabetes (40), conditions for which exercise is indicated and beneficial. However, patients with these conditions need to be carefully monitored for the presence of symptoms that would contraindicate exercise and require medical referral (e.g., chest pain, shortness of breath with mild exertion, palpitations, syncope, etc). Health care providers also need to continue to address exercise adherence in this patient population by providing education on the positive effects of exercise on physical fitness and the healing process. Routine monitoring of wound health is also imperative to ensure proper healing is occurring.

\section{Conclusions}

Venous leg ulcers are the most common etiology of lower extremity ulceration. They pose a financial burden on society and increase in prevalence with age. The chronic nature of 
the disorder and high recidivism rate are, in part, the driving forces behind efforts to determine the most effective management options to achieve complete wound healing in a time efficient manner. While medical treatment of VLUs include wound debridement, infection control, proper wound dressing, and therapeutic modalities, compression therapy and elevation are the most common and effective treatment option for VLUs. When combined with these treatments, exercise intervention (e.g., aerobic, resistance, and flexibility exercises) will likely improve the healing of VLUs in a cost efficient manner and should be strongly considered in the routine management of patients with VLUs.

\section{Financial Disclosure and Conflict of Interest Statement}

We affirm that we have no financial affiliation (including research funding) or involvement with any commercial organization that has a direct financial interest in any matter included in this manuscript. There are also no conflicts of interest (ie, personal associations or involvement as a director, officer, or expert witness) associated with this manuscript.

\section{About the Authors}

Dr. Samantha Barker, DPT is a physical therapist who currently works in an orthopedic and acute care setting. Her research interests include the promotion of health and wellness involving the effects of exercise and rehabilitation strategies on patients in the orthopedic and acute care settings.

Dr. Michael Ross, PT, DHSc is a physical therapist with research interests in pain management and physical therapy outcomes.

Dr. Kehua Zhou, MD, DPT is a hospitalist physician with research interests in wound care, physical therapy, oncology, and hospital medicine.

\section{References}

1. O'Meara S, Al-Kurdi D, Ovington LG. Antibiotics and antiseptics for venous leg ulcers. Cochrane Database Syst Rev. 2008;(1):CD003557.

2. Alavi A, Sibbald RG, Phillips TJ, et al. What's new: management of venous leg ulcers: approach to venous leg ulcers. J Am Acad Dermatol. 2016;74:627-640.

3. Valencia IC, Falabella A, Kirsner RS, et al. Chronic venous insufficiency and venous leg ulceration. J Am Acad Dermatol. 2001;44:401-421.

4. Rice JB, Desai U, Cummings AKG, et al. Burden of diabetic foot ulcers for Medicare and private insurers. Diabetes Care. 2014;37:651-658.

5. Briggs M, Closs SJ. The prevalence of leg ulceration: a review of the literature. EWMA Journal. 2003;3:14-20.

6. de Araujo T, Valencia I, Federman DG, et al. Managing the patient with venous ulcers. Ann Intern Med. 2003;138:326-334.

7. Hodde J, Allam R. Submucosa wound matrix for chronic wound healing. Wounds. 2007; 19:157-163. 
8. De Araujo TS, Hexsel CL, Kirsner RS. Treatment of venous ulcers. Curr Treat Options Cardiovasc Med. 2005;7:131-138.

9. Kurz X, Kahn SR, Abenhaim L, et al. Chronic venous disorders of the leg: epidemiology, outcomes, diagnosis and management. Summary of an evidencebased report of the VEINES task force. Venous Insufficiency Epidemiologic and Economic Studies. Int Angiol. 1999;18:83-102.

10. Heit JA. Venous thromboembolism epidemiology: implications for prevention and management. Semin Thromb Hemost. 2002;28:3-13.

11. Marieb EN. Essentials of Human Anatomy and Physiology (8th edn). San Francisco, CA: Benjamin-Cummings Pub Co., 2006.

12. Doughty DB, Holbrook R. Lower extremity ulcers of vascular etiology. In: Bryant RA, Nix DP, eds. Acute and Chronic Wounds. 3rd ed. Maryland Heights, MO: Mosby, 2007.

13. Kalra, M., Gloviczki, P. Surgical treatment of venous ulcers: role of subfascial endoscopic perforator vein ligation. Surg Clin North Am. 2003;83:671-675.

14. Yim E, Kirsner RS, Gailey RS, et al. Effect of physical therapy on wound healing and quality of life in patients with venous leg ulcers. JAMA Dermatology. 2015;151:320.

15. Etufugh CN, Phillips TJ. Venous ulcers. Clin Dermatol. 2007;25(1):121-130.

16. Raffetto JD. Pathophysiology of wound healing and alterations in venous leg ulcers - review. Phlebology 2016;31:56-62.

17. Mannello F, Raffetto JD. Matrix metalloproteinase activity and glycosaminoglycans in chronic venous disease: the linkage among cell biology, pathology and translational research. Am J Transl Res. 2011;3:149-158.

18. Singer AJ, Tassiopoulos A, Kirsner RS. Evaluation and management of lowerextremity ulcers. N Engl J Med. 2017;377:1559-1567.

19. Yim E, Vivas A, Maderal A, et al. Neuropathy and ankle mobility abnormalities in patients with chronic venous disease. JAMA Dermatol. 2014;150:385-389.

20. Dix FP, Brooke R, McCollum CN. Venous disease is associated with an impaired range of ankle movement. Eur J Vasc Endovasc Surg. 2003;25:556-561.

21. Carpentier PH, Maricq HR, Biro C, et al. Prevalence, risk factors, and clinical patterns of chronic venous disorders of lower limbs: a population-based study in France. J Vasc Surg. 2004;40:650-659.

22. Nelson EA, Bell-Syer SE, Cullum NA. Compression for preventing recurrence of venous ulcers. Cochrane Database Syst Rev. 2000;(4):CD002303.

23. Carville K. Wound Care Manual. Osborne Park, WA: Silver Chain Nursing Association, 2005.

24. Nelzén O, Bergqvist D, Lindhagen A. Venous and non-venous leg ulcers: clinical history and appearance in a population study. Br J Surg. 1994;81:182-187.

25. Stacey MC, Burnand KG, Layer GT, et al. Measurement of the healing of venous ulcers. Aust N Z J Surg. 1991;61:844-848.

26. European Wound Management Association. Position Document: Identifying Criteria for Wound Infection. London: MEP Ltd., 2005. 
27. König M, Vanscheidt W, Augustin M, et al. Enzymatic versus autolytic debridement of chronic leg ulcers: a pro-spective randomised trial. J Wound Care. 2005;14:320-323.

28. Stevens DL, Bisno AL, Chambers HF, et al. Practice guidelines for the diagnosis and management of skin and soft tissue infections: 2014 update by the Infectious Diseases Society of America. Clin Infect Dis. 2014;59:e10-52.

29. Serra R, Grande R, Butrico L, et al. Chronic wound infections: the role of Pseudomonas aeruginosa and Staphylococcus aureus. Expert Rev Anti Infect Ther. 2015;13:605-613.

30. White RJ, Cutting KF. Critical colonization--the concept under scrutiny. Ostomy Wound Manage. 2006;52:50-56.

31. O'Meara S, Martyn-St James M. Foam dressings for venous leg ulcers. Cochrane Database Syst Rev 2013;(5):CD009907.

32. Thomas DR. Managing venous stasis disease and ulcers. Clin Geriatr Med. 2013;29:415-424.

33. Meaume S, Dompmartin A, Lok C, et al. Quality of life in patients with leg ulcers: results from CHALLENGE, a double-blind randomised controlled trial. J Wound Care. 2017;26:368-379.

34. O'Meara S, Cullum N, Nelson EA, et al. Compression for venous leg ulcers. Cochrane Database Syst Rev 2012;(11):CD000265.

35. Meagher H, Ryan D, Clarke-Moloney M, et al. An experimental study of prescribed walking in the management of venous leg ulcers. J Wound Care. 2012;21:421-2, 424-6, 428 passim.

36. Kurd SK, Hoffstad OJ, Bilker WB, et al. Evaluation of the use of prognostic information for the care of individuals with venous leg ulcers or diabetic neuropathic foot ulcers. Wound Repair Regen. 2009;17:318-325.

37. O'Brien J, Finlayson K, Kerr G, et al. Evaluating the effectiveness of a selfmanagement exercise intervention on wound healing, functional ability and health-related quality of life outcomes in adults with venous leg ulcers: a randomised controlled trial. Int Wound J. 2016;14:130-137.

38. Pieper B, Templin TN, Birk TJ, et al. Chronic venous disorders and injection drug use: impact on balance, gait, and walk speed. J Wound Ostomy Continence Nurs. 2008;35:301-310.

39. Klonizakis M, Tew GA, Gumber A, et al. Supervised exercise training as an adjunct therapy for venous leg ulcers: a randomized controlled feasibility trial. Br J Dermatol. 2018;178:1072-1082.

40. Margolis DJ, Knauss J, Bilker W. Medical conditions associated with venous leg ulcers. Br J Dermatol. 2004;150:267-273. 


\section{Appendix}

Table 1: Study characteristics that evaluated the effect of exercise in patients with venous leg ulcers (VLU = venous leg ulcer)

\begin{tabular}{|c|c|c|c|}
\hline Study & $\begin{array}{c}\text { Participant } \\
\text { Characteristics }\end{array}$ & Intervention & Outcomes \\
\hline $\begin{array}{l}\text { Klonizakis } \\
\text { et al (39) }\end{array}$ & $\begin{array}{l}\text { - } 39 \text { participants } \\
\text { with at least } 1 \text { VLU } \\
\text { (diameter of at least } \\
1 \mathrm{~cm} \text { ) } \\
-23 \text { males, } 16 \\
\text { females } \\
\text { - Mean age: } \\
63.5 \pm 12.8 \text { years }\end{array}$ & $\begin{array}{l}\text { - Control group }(\mathrm{n}=21) \text { : } \\
\text { standard compression } \\
\text { therapy for } 12 \text { weeks } \\
\text { - Exercise group }(\mathrm{n}=18) \text { : } \\
\text { standard compression } \\
\text { therapy and supervised } \\
\text { exercise for } 12 \text { weeks ( } 3 \\
\text { sessions each week) }\end{array}$ & $\begin{array}{l}\text { - Participants in the exercise group } \\
\text { demonstrated higher mean values } \\
\text { in the physical fitness tests (6- } \\
\text { minute walk test, chair sit and } \\
\text { reach, chair sit and stand) and } \\
\text { ankle range of motion at } 3 \text { months, } \\
\text { but stabilized in all measures in } \\
\text { relation to the non-exercise group } \\
\text { by } 12 \text { months } \\
\text { - At } 1 \text { year, median VLU healing } \\
\text { time was lower in the exercise } \\
\text { group (13 versus } 35 \text { weeks) and } \\
\text { mean costs for care were } 3 \text { times } \\
\text { higher for those individuals in the } \\
\text { control group }\end{array}$ \\
\hline $\begin{array}{l}\text { Meagher et } \\
\text { al (35) }\end{array}$ & $\begin{array}{l}\text { - } 35 \text { participants } \\
\text { with a newly } \\
\text { diagnosed VLU } \\
\text { - } 17 \text { males, } 18 \\
\text { females } \\
\text { - Median age: } 71 \\
\text { years (range=32 to } \\
91 \text { years) }\end{array}$ & $\begin{array}{l}\text { - Control group ( } \mathrm{n}=17) \text { : } \\
\text { multilayer compression } \\
\text { stockings for } 12 \text { weeks; no } \\
\text { specific advice regarding } \\
\text { exercise } \\
\text { - Exercise group ( } \mathrm{n}=18) \text { : } \\
\text { multilayer compression } \\
\text { stockings for } 12 \text { weeks } \\
\text { and instructed to try and } \\
\text { increase their walking to } \\
10,000 \text { steps a day }\end{array}$ & $\begin{array}{l}\text { - } 33 \text { percent of participants in the } \\
\text { exercise group achieved an } \\
\text { average of } 10,000 \text { steps per day } \\
\text { - Mean daily steps at week } 4: 5006 \\
\text { for the participants in the control } \\
\text { group and } 8161 \text { for the } \\
\text { participants in the exercise group } \\
\text { - } 67 \text { percent of the participants in } \\
\text { the exercise group achieved } \\
\text { complete VLU healing by } 8 \text { weeks, } \\
\text { compared with } 35 \text { percent of } \\
\text { individuals in the control group } \\
\text { - Participants who took more steps } \\
\text { at both baseline and the } 4 \text {-week } \\
\text { assessment healed quicker than } \\
\text { those who took fewer steps }\end{array}$ \\
\hline $\begin{array}{l}\mathrm{O}^{\prime} \text { Brien et al } \\
(37)\end{array}$ & $\begin{array}{l}\text { - } 63 \text { participants } \\
\text { with VLUs } \\
\text { - } 32 \text { males, } 31 \\
\text { females } \\
\text { - Mean age: } \\
71.5 \pm 14.6 \text { years }\end{array}$ & $\begin{array}{l}\text { - Control group }(\mathrm{n}=32) \text { : } \\
\text { usual wound care plus } \\
\text { telephone calls for } 12 \\
\text { weeks } \\
\text { - Exercise group }(\mathrm{n}=31) \text { : } \\
\text { usual wound care and a } \\
\text { 12-week home-based } \\
\text { progressive resistance } \\
\text { exercise program for the } \\
\text { calf musculature with a } \\
\text { telephone coaching } \\
\text { component }\end{array}$ & $\begin{array}{l}\text { - } 77 \text { percent of those in the } \\
\text { intervention group healed } \\
\text { compared to } 53 \text { percent of those in } \\
\text { the usual care group } \\
\text { - } 95 \text { percent of those in the } \\
\text { intervention group who adhered } \\
\text { to the exercise protocol } 75 \% \text { or } \\
\text { more of the time healed in } 12 \\
\text { weeks }\end{array}$ \\
\hline
\end{tabular}


Table 2: Supervised exercise program for patients

with venous leg ulcers modified from Klonizakis et al. (39)

\begin{tabular}{|c|c|c|}
\hline Exercise & Dosage & Comment \\
\hline Warm-up & $\begin{array}{l}\text { Each session began with } \\
\text { a 5-minute warm-up of } \\
\text { low-intensity treadmill } \\
\text { walking or cycling }\end{array}$ & $\begin{array}{l}\text { The target for the warm-up period was for the } \\
\text { participant to exercise at an exertion level of no } \\
\text { higher than } 11 \text { (light) on Borg's 6-20 RPE scale. }\end{array}$ \\
\hline Calf Stretch & $\begin{array}{l}3 \text { repetitions for } 20- \\
\text { seconds, held at the } \\
\text { point of mild discomfort }\end{array}$ & \\
\hline Hamstring Stretch & $\begin{array}{l}3 \text { repetitions for } 20- \\
\text { seconds, held at the } \\
\text { point of mild discomfort }\end{array}$ & \\
\hline Quadriceps Stretch & $\begin{array}{l}3 \text { repetitions for } 20- \\
\text { seconds, held at the } \\
\text { point of mild discomfort }\end{array}$ & \\
\hline $\begin{array}{l}\text { *Standing Bilateral Heel } \\
\text { Raise }\end{array}$ & $\begin{array}{l}2 \text { to } 3 \text { sets of } 10 \text { to } 15 \\
\text { repetitions to the point } \\
\text { of moderate muscle } \\
\text { fatigue }\end{array}$ & $\begin{array}{l}\text { If the patient is unsteady, they may start in } \\
\text { sitting; alternatively, if the patient can complete } \\
30 \text { bilateral heel raises without difficulty, } \\
\text { consider progressing to a single-leg heel raise. }\end{array}$ \\
\hline *Partial Squats & $\begin{array}{l}2 \text { to } 3 \text { sets of } 10 \text { to } 15 \\
\text { repetitions to the point } \\
\text { of moderate muscle } \\
\text { fatigue }\end{array}$ & $\begin{array}{l}\text { Instruct the patient to lower into a squat as far } \\
\text { as is comfortable for them. Place a chair behind } \\
\text { them in case they start to fall backwards while } \\
\text { completing the task. }\end{array}$ \\
\hline${ }^{*}$ Chair Sit-to-Stand & $\begin{array}{l}2 \text { to } 3 \text { sets of } 10 \text { to } 15 \\
\text { repetitions to the point } \\
\text { of moderate muscle } \\
\text { fatigue }\end{array}$ & $\begin{array}{l}\text { If the patient is unsteady, start with allowing } \\
\text { them to place hands on a plinth for balance. }\end{array}$ \\
\hline $\begin{array}{l}\text { †Aerobic Exercise: } \\
\begin{aligned} & \text { 1. } \text { Walking } \\
& \text { 2. } \text { Cycling } \\
& \text { 3. } \text { Combination of } \\
& \text { Both } \\
&\end{aligned}\end{array}$ & $\begin{array}{l}3 \text { times per week for } 30- \\
\text { minutes each }\end{array}$ & $\begin{array}{l}\text { Patient should complete one or a combination of } \\
\text { the two exercises for a total of } 30 \text { minutes. The } \\
\text { intensity of exercise is guided by the use of } \\
\text { Borg's 6-20 RPE scale, encouraging exercise at } \\
\text { an exertion level of 12-14 (somewhat hard). }\end{array}$ \\
\hline
\end{tabular}

$\mathrm{RPE}=$ rating of perceived exertion.

*The exercises involved dynamic body-weight exercises with or without the use of dumbbells.

tExercise mode is determined by the physical function and preference of participants, however, treadmill hill-walking was the preferred mode, since it promotes greater recruitment of the calf musculature than cycling. 
Table 3: Home exercise program for patients with venous leg ulcers modified from O’Brien et al (37).

\begin{tabular}{|c|c|c|}
\hline Exercise & Dosage & Comment \\
\hline $\begin{aligned} \text { Ankle Active Range of Motion } \\
\text { 1. Ankle Dorsiflexion \& } \\
\text { Plantarflexion } \\
\text { 2. Ankle Inversion \& } \\
\text { Eversion } \\
\text { 3. Ankle Circles (clockwise } \\
\text { \& counterclockwise) } \\
\end{aligned}$ & $\begin{array}{l}3 \text { to } 5 \text { sets of } 10 \text { to } 20 \\
\text { repetitions }\end{array}$ & \\
\hline${ }^{*}$ Calf Stretch & $\begin{array}{l}3 \text { to } 5 \text { repetitions for } 20- \\
\text { seconds, held at the point } \\
\text { that elicited comfortable } \\
\text { tension but no pain. }\end{array}$ & \\
\hline${ }^{*}$ Hamstring Stretch & $\begin{array}{l}3 \text { to } 5 \text { repetitions for } 20- \\
\text { seconds, held at the point } \\
\text { that elicited comfortable } \\
\text { tension but no pain. }\end{array}$ & \\
\hline Sitting Bilateral Heel Raise & $\begin{array}{l}\text { Begin with } 3 \text { sets of } 10 \\
\text { repetitions daily and } \\
\text { progress to } 3 \text { sets of } 25 \\
\text { repetitions daily }\end{array}$ & $\begin{array}{l}\text { If the patient can complete } 3 \text { sets of } 25 \\
\text { bilateral heel raises in sitting without } \\
\text { difficulty, consider progressing to a } \\
\text { standing bilateral heel raise, and then } \\
\text { a standing bilateral single-leg heel } \\
\text { raise. }\end{array}$ \\
\hline tWalking & $\begin{array}{l}3 \text { times per week aiming } \\
\text { for } 30 \text {-minutes each } \\
\text { session }\end{array}$ & $\begin{array}{l}\text { A target of } 150 \text { minutes ( } 30 \text { minutes } \\
\text { over } 5 \text { days per week) of low to } \\
\text { moderate intensity walking, was } \\
\text { encouraged (as defined by a score } \\
\text { between 9-14 on Borg's 6-20 RPE } \\
\text { scale). }\end{array}$ \\
\hline
\end{tabular}

*Stretching was recommended prior to and following each exercise session.

tAs most patients are relatively inactive at baseline, increases in walking are initially small and gradually increase towards the goal of 30 minutes per day of low-moderate intensity. 
Figure 1: Venous leg ulcer on the lower leg. The ulcer is characteristically shallow in depth and irregularly shaped with well-defined margins (image courtesy of Dr. David Draughn and the Vein Specialists of the Carolinas, Charlotte, North Carolina)

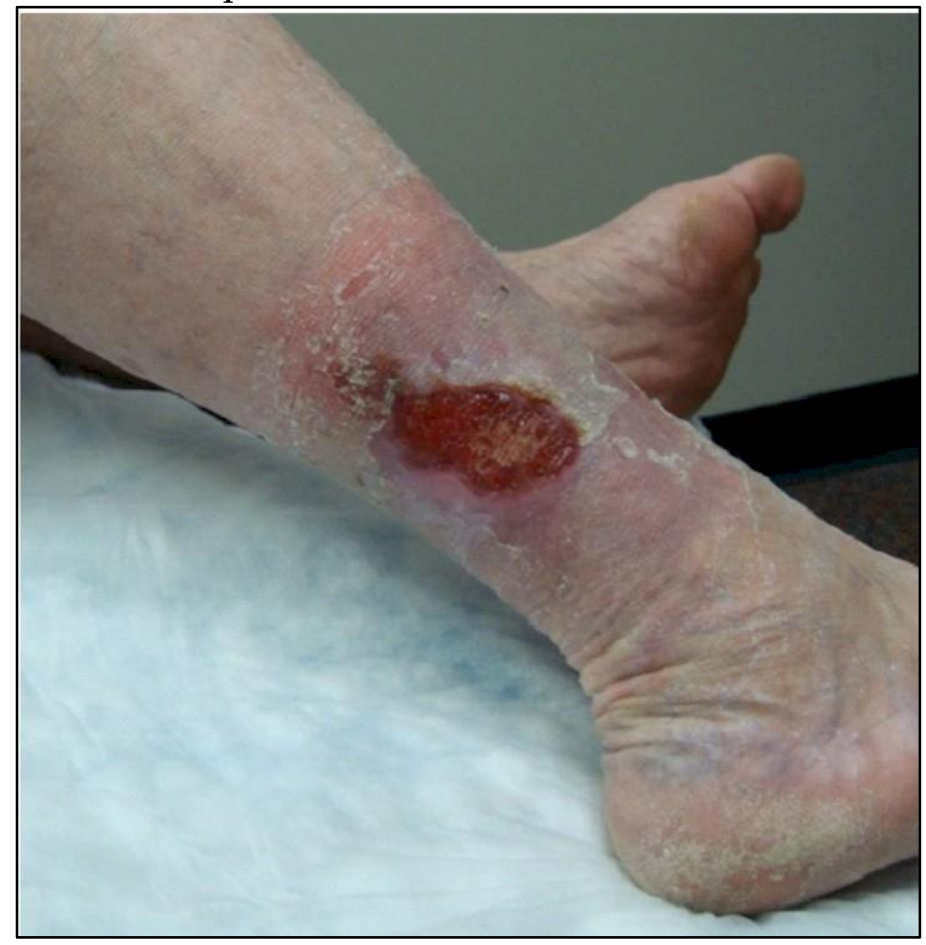


Creative Commons licensing terms

Author(s) will retain the copyright of their published articles agreeing that a Creative Commons Attribution 4.0 International License (CC BY 4.0) terms will be applied to their work. Under the terms of this license, no permission is required from the author(s) or publisher for members of the community to copy, distribute, transmit or adapt the article content, providing a proper, prominent and unambiguous attribution to the authors in a manner that makes clear that the materials are being reused under permission of a Creative Commons License. Views, opinions and conclusions expressed in this research article are views, opinions and conclusions of the author(s). Open Access Publishing Group and European Journal of Social Sciences Studies shall not be responsible or answerable for any loss, damage or liability caused in relation to/arising out of conflicts of interest, copyright violations and inappropriate or inaccurate use of any kind content related or integrated into the research work. All the published works are meeting the Open Access Publishing requirements and can be freely accessed, shared, modified, distributed and used in educational, commercial and non-commercial purposes under a Creative Commons Attribution 4.0 International License (CC BY 4.0). 